\title{
Faktor-faktor yang Berhubungan dengan Prestasi Belajar Mahasiswa di Akademi Kebidanan Prima Husada Bogor
}

\author{
Wiwit wijayanti \\ (Dosen Program studi Kebidanan, Fakultas Ilmu Kesehatan Universitas MH. Thamrin)
}

\begin{abstract}
ABSTRAK
Prestasi belajar adalah penguasaan pengetahuan atau keterampilan yang dikembangkan oleh mata pelajaran, lazimnya ditunjukkan dengan nilai tes atau angka nilai yang diberikan oleh guru/dosen.Tujuan dalam penelitian ini yaitu Untuk mengetahui faktor - faktor yang berhubungan dengan prestasi belajar di Akademi Kebidanan Prima Husada Bogor Tahun 2015.

Metode yang digunakan adalah analitik dengan pendekatan Cross sectional.Populasinya adalah seluruh mahasiswa Akademi kebidanan Prima Husada Bogor.Sampel yang digunakan adalah 150 mahasiswa.Mata kuliah yang dijadikan sampel adalah asuhan kebidanan persalinan.Teknik sampel secara Purposive sampling.

Analisis univariat menunjukkan bahwa $79 \%$ mahasiswa yang mendapat prestasi belajar ASKEB Persalinan rendah. Hasil uji Chi-square menyatakan bahwa dari lima variabel yang diteliti memiliki hubungan yang bermakna dengan nilai p-Value dari masing-masing variabel yaitu kecerdasan emosional $(p=0,005)$, minat belajar $(p=0,000)$, sikap belajar $(p=0,003)$, teman sebaya $(p=0,000)$ dan motivasi $(p=0,002)$. Berdasarkan hasil penelitian, dapat disimpulkan bahwa rendahnya prestasi belajar ASKEB Persalinan yang meliputi kecerdasan emosional, minat belajar, sikap belajar, teman sebaya dan motivasi belajar dapat berpengaruh terhadap prestasi belajar.

Saran untuk institusi pendidikan diharapkan untuk dapat meningkatkan kecerdasan emosional mahasiswa agar lebih percaya diri, menumbuhkan minat mahasiswa dalam belajar, memantau sikap mahasiswa agar tidak tumbuh sikap yang negatif, meningkatkan keakraban antara dosen dengan mahasiswa agar tidak terpengaruh oleh teman sebaya yang mengarah pada hal kurang baik dan berikan pada mahasiswa motivasi yang membangun agar mereka memiliki semangat untuk maju. Kata Kunci:Prestasi belajar, Prima Husada
\end{abstract}




\section{PENDAHULUAN}

Asuhan Kebidanan Persalinan dengan pendekatan manajemen kebidanan yang didasari konsep-konsep, sikap dan keterampilan serta evidance based. Ruang lingkup asuhan kebidanan II meliputi: konsep dasar persalinan, beberapa faktor yang mempengaruhi persalinan, proses adaptasi psikologi dalam persalinan, kebutuhan dasar pada ibu dalam proses persalinan, asuhan pada setiap kala persalinan, deteksi komplikasi persalinan dan cara penanganannya, asuhan kebidanan pada bayi segera setelah lahir, cara pendokumentasian asuhan masa persalinan.

Mata kuliah Asuhan Kebidanan Persalinan sangat penting di kuasai oleh para mahasiswa kebidanan dikarenakan Asuhan Kebidanan Persalinan merupakan matakuliah inti yang harus di pahami oleh mahasiswa, dampak ketika mereka tidak dapat memahami atau pun menguasai mata kuliah Asuhan Kebidanan Persalinan dihawatirkan ketika terjun di lapangan mereka tidak dapat menangani persalina dengan baik dan benar, sehingga dikhawatirkan mereka akan menyumbang nilai kematian pada ibu atau bayi.

Karena Kematian ibu di Indonesia 50\% terjadi di 5 Provinsi yaitu Provinsi Jawa Barat (19,8\%), Jawa Tengah (15,3\%), NTT (5,6\%), Banten (4,7\%) dan Jawa Timur (4,3\%). Terutama Jawa Barat Masih tingginya angka kematian ibu dan bayi itu, mengakibatkan Indek Pembangunan Manusia (IPM) Jabar pada 2013 masih di angka 73,40 Kondisi itu masih cukup jauh dari target IPM Jabar yang seharusnya dicapai 80 pada tahun 2015 (Puslitbang Jabar 2014).

Menurut kamus besar bahasa indonesia Prestasi belajar adalah penguasaan pengetahuan atau keterampilan yang dikembangkan oleh mata pelajaran, lazimnya ditunjukkan dengan nilai tes atau angka nilai yang diberikan oleh guru/dosen.

Adapun faktor yang terkait dengan prestasi belajar terdiri dari dua faktor yaitu faktor internal (Fisiologis, Psikologis, Tingkat kecerdasan atau inteligensi, Sikap belajar, Bakat, Minat Belajar, Motivasi) dan faktor eksternal (Lingkungan sosial, Faktor pendekatan belajar, Lingkungan nonsosial).

Menurut penelitian yang dilakukan oleh Palifiana (2013) mengenai pengaruh motivasi belajar dan keterampilan praktik laboratorium terhadap prestasi belajar asuhan kebidanan II (persalinan) mahasiswa akademi kebidanan nyai ahmad dahlan yogyakarta.Hasil uji hipotesis menunjukkan bahwa : (1). Ha diterima karena $p$ value 0,000 yang artinya terdapat pengaruh yang signifikan motivasi belajar terhadap prestasi belajar asuhan kebidanan II (persalinan),

Dasar peneliti ingin melakukan penelitian ini berasal dari study pendahuluan hasil belajar mahasiswa Tingkat II tentang Mata Kuliah Asuhan Kebidanan Persalinan dengan hasil belajar yang kurang memuaskan dari 240 mahasiswa di dapatkan 132 mahasiswa yang mendapat nilai kurang memuaskan dengan persentase hasil belajar yang kurang memuaskan 55\% terkait dengan hal tersebut peneliti ingin mengetahui faktor yang berhubungan dengan prestasi belajar mahasiswa.

\section{METODE}

Metode yang digunakan adalah analitik dengan pendekatan Cross sectional.Populasinya adalah seluruh mahasiswa Akademi kebidanan Prima Husada Bogor.Sampel yang digunakan adalah 150 mahasiswa.Mata kuliah yang dijadikan sampel adalah asuhan kebidanan persalinan. Teknik sampel secara Purposive sampling

\section{HASIL PENELITIAN}

Analisis Univariat

Dari hasil pengolahan data dapat diketahui frekuensi tiap-tiap variabel sebagai berikut: 
Tabel1

Distribusi Frekuensi Prestasi Belajar pada Mahasiswa di Akademi Kebidanan Prima Husada Bogor

\begin{tabular}{rccc}
\hline & VARIABEL & n & $\%$ \\
\hline Prestasi belajar & & \\
- Rendah & 119 & 79,3 \\
- Tinggi & 31 & 21,7 \\
\hline Total & 150 & 100 \\
\hline
\end{tabular}

Berdasarkan tabel 1 di atas diketahui distribusi frekuensi responden berdasarkan Prestasi Belajar pada Mahasiswa di Akademi Kebidanan Prima Husada Bogor bahwa dari 150 responden terbanyak adalah kelompok dengan prestasi belajar ASKEB Persalinan yang rendah yaitu sebanyak 119 responden $(79,3 \%)$

Tabel 2

Distribusi Frekuensi Kecerdasan Emosional, Minat Belajar, Sikap Belajar, Teman Sebaya, dan Motivasi Belajar pada Mahasiswa AKBID Prima Husada Bogor

\begin{tabular}{|c|c|c|}
\hline VARIABEL & $\mathbf{n}$ & $\%$ \\
\hline $\begin{array}{c}\text { Kecerdasan Emosional } \\
-\quad \text { Kurang Baik (bila }<\text { Mean }) \\
-\quad \text { Baik (bila } \geq \text { Mean }) \\
\end{array}$ & $\begin{array}{l}78 \\
72 \\
\end{array}$ & $\begin{array}{c}52,0 \\
480 \\
\end{array}$ \\
\hline $\begin{aligned} \text { Minat } & \text { Belajar } \\
- & \text { Kurang baik (bila < Mean) } \\
- & \text { Baik (bila } \geq \text { Mean) }\end{aligned}$ & $\begin{array}{c}123 \\
27\end{array}$ & $\begin{array}{l}82,0 \\
18,0\end{array}$ \\
\hline $\begin{array}{cc}\text { Sikap } & \text { Belajar } \\
- & \text { Negatif }(\text { bila }<\text { Mean }) \\
- & \text { Positif (bila } \geq \text { Mean) }\end{array}$ & $\begin{array}{l}94 \\
56 \\
\end{array}$ & $\begin{array}{l}62,7 \\
37,3 \\
\end{array}$ \\
\hline $\begin{aligned} \text { Teman Sebaya } \\
-\quad \text { Terpengaruh }(\text { bila }<\text { Mean) } \\
-\quad \text { Tidak Terpengaruh }(\text { bila } \geq \text { Mean })\end{aligned}$ & $\begin{array}{c}116 \\
34\end{array}$ & $\begin{array}{l}77,3 \\
22,7\end{array}$ \\
\hline $\begin{array}{l}\text { Motivasi Belajar } \\
-\quad \text { Kurang baik ( bila }<\text { Mean) } \\
-\quad \text { Baik (bila } \geq \text { Mean) }\end{array}$ & $\begin{array}{l}79 \\
71\end{array}$ & $\begin{array}{l}52,7 \\
47,3\end{array}$ \\
\hline
\end{tabular}

Berdasarkan tabel 2 di atas distribusi frekuensi responden berdasarkan penelitian yang dilakukan pada mahasiswa D III Kebidanan Tingkat II di Akademi Kebidanan Prima Husada Bogor bahwa dari 150 responden dengan kecerdasan emosional yang kurang baik yaitu sebanyak 78 responden $(52,0 \%)$ serta mahasiswa yang kurang baik minat belajarnya sebanyak 123 responden $(82,0 \%)$ selain itu diketahui juga sikap belajar yang negatif sebanyak 94 responden $(62,7 \%)$ kemudian terpengaruh teman sebaya sebanyak 116 responden $(77,3 \%)$ dan mahasiswa dengan motivasi belajar yang kurang baik sebanyak 79 responden $(52,7 \%)$. 


\section{Analisa Bivariat}

Tabel 3

Hubungan Kecerdasan Emosional dengan Prestasi Belajar Mata Kuliah Asuhan Kebidanan Persalinan di Akademi Kebidanan Prima Husada Bogor

\begin{tabular}{|c|c|c|c|c|c|c|c|c|}
\hline \multirow[t]{3}{*}{$\begin{array}{c}\text { Kecerdasan } \\
\text { Emosional }\end{array}$} & \multicolumn{4}{|c|}{$\begin{array}{c}\text { Prestasi Belajar ASKEB } \\
\text { Persalinan }\end{array}$} & \multicolumn{2}{|c|}{ Jumlah } & \multirow[t]{3}{*}{ Nilai $\mathbf{P}$} & \multirow[t]{3}{*}{ OR } \\
\hline & \multicolumn{2}{|c|}{ Rendah } & \multicolumn{2}{|c|}{ Tinggi } & & & & \\
\hline & n & $\%$ & $\mathrm{n}$ & $\%$ & $\mathbf{N}$ & $\%$ & & \\
\hline $\begin{array}{cc}\text { - } & \text { Kurang } \\
\text { Baik } \\
\text { - } \quad \text { Baik }\end{array}$ & $\begin{array}{l}69 \\
50\end{array}$ & $\begin{array}{l}88,5 \\
69,4\end{array}$ & $\begin{array}{c}9 \\
22\end{array}$ & $\begin{array}{l}11,5 \\
30,6\end{array}$ & $\begin{array}{l}78 \\
72\end{array}$ & $\begin{array}{l}100.0 \\
100.0\end{array}$ & 0.005 & $\begin{array}{c}3.373 \\
(1.432-7.946)\end{array}$ \\
\hline
\end{tabular}

Berdasarkan data tabel 3 di atas menunjukkan hubungan antara kecerdasan emosional dengan prestasi belajar ASKEB Persalinan. Hasilnya adalah sebanyak 69 responden $(88,5 \%)$ dengan prestasi belajar ASKEB Persalinan rendah diperoleh dari kecerdasan emosional yang kurang baik. Dalam penelitian ini kelompok responden kecerdasan emosional yang kurang baik pada mata kuliah ASKEB Persalinan lebih besar dari pada responden dengan kecerdasan emosional yang baik.

Berdasarkan uji statistik didapatkan $\mathrm{P}$ value $<\alpha(0,005<0,05)$ artinya ada hubungan yang signifikan antara kecerdasan emosional dengan prestasi belajar ASKEB persalinan. Mahasiswa yang kecerdasan emosionalnya kurang baik memiliki peluang atau OR untuk mendapatkan prestasi belajar ASKEB persalinan yang rendah sebesar 3,4 kali lebih tinggi dibandingkan dengan mahasiswa yang yang kecerdasan emosionalnya baik dengan rentang CI antara $(1,4-7,9)$

\section{Tabel 4}

\begin{tabular}{|c|c|c|c|c|c|c|c|c|}
\hline \multirow{3}{*}{$\begin{array}{l}\text { Minat } \\
\text { Belajar }\end{array}$} & \multicolumn{4}{|c|}{$\begin{array}{c}\text { Prestasi Belajar ASKEB } \\
\text { Persalinan } \\
\end{array}$} & \multirow{2}{*}{\multicolumn{2}{|c|}{ Jumlah }} & \multirow[t]{3}{*}{ Nilai $\mathbf{P}$} & \multirow[t]{3}{*}{ OR } \\
\hline & \multicolumn{2}{|c|}{ Rendah } & \multicolumn{2}{|c|}{ Tinggi } & & & & \\
\hline & $\mathbf{n}$ & $\%$ & $\mathbf{n}$ & $\%$ & $\mathbf{n}$ & $\%$ & & \\
\hline 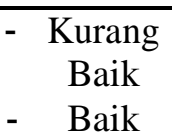 & $\begin{array}{r}107 \\
12\end{array}$ & $\begin{array}{l}87,0 \\
44,4\end{array}$ & $\begin{array}{l}16 \\
15\end{array}$ & $\begin{array}{l}13,0 \\
55,6\end{array}$ & $\begin{array}{c}123 \\
27\end{array}$ & $\begin{array}{l}100.0 \\
100.0\end{array}$ & 0.000 & $\begin{array}{c}8.359 \\
(3.321-21.042)\end{array}$ \\
\hline
\end{tabular}

Berdasarkan data tabel 4 di atas menunjukkan hubungan antara minat belajar dengan prestasi belajar ASKEB Persalinan. Hasilnya adalah sebanyak 107 responden (87,0\%) dengan prestasi belajar ASKEB Persalinan rendah diperoleh dari minat belajar yang kurang baik. Dalam penelitian ini kelompok responden dengan minat belajar yang kurang baik pada mata kuliah ASKEB Persalinan lebih besar dari pada responden dengan minat belajar yang baik.

Berdasarkan uji statistik didapatkan $\mathrm{P}$ value $<\alpha(0,000<0,05)$ artinya ada hubungan yang signifikan antara minat belajar dengan rendahnya prestasi belajar ASKEB persalinan. Mahasiswa yang kurang baik minat belajarnya memiliki peluang atau OR untuk mendapat prestasi belajar ASKEB persalinan rendah sebesar 8,4 kali lebih tinggi dibanding dengan mahasiswa yang baik minat belajarnya dengan rentang CI antara $(3,3-21,0)$. 
Tabel 5

Hubungan Sikap Belajar dengan Prestasi Belajar Belajar Mata Kuliah Asuhan Kebidanan Persalinan di Akademi Kebidana Prima Husada Bogor

\begin{tabular}{|c|c|c|c|c|c|c|c|c|}
\hline \multirow[t]{3}{*}{$\begin{array}{l}\text { Sikap } \\
\text { Belajar }\end{array}$} & \multicolumn{4}{|c|}{$\begin{array}{c}\text { Prestasi Belajar ASKEB } \\
\text { Persalinan }\end{array}$} & \multicolumn{2}{|c|}{ Jumlah } & \multirow[t]{3}{*}{ Nilai $P$} & \multirow[t]{3}{*}{ OR } \\
\hline & \multicolumn{2}{|c|}{ Rendah } & \multicolumn{2}{|c|}{ Tinggi } & & & & \\
\hline & $\mathbf{N}$ & $\%$ & n & $\%$ & $\mathbf{n}$ & $\%$ & & \\
\hline 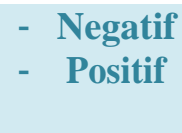 & $\begin{array}{l}82 \\
37\end{array}$ & $\begin{array}{l}87,2 \\
66,1\end{array}$ & $\begin{array}{l}12 \\
19\end{array}$ & $\begin{array}{l}12,8 \\
33,9\end{array}$ & $\begin{array}{l}94 \\
56\end{array}$ & $\begin{array}{l}100.0 \\
100.0\end{array}$ & 0.003 & $\begin{array}{c}3.509 \\
(1.545-7970)\end{array}$ \\
\hline
\end{tabular}

Berdasarkan data tabel 5 di atas menunjukkan hubungan antara sikap belajar dengan prestasi belajar ASKEB Persalinan. Hasilnya adalah sebanyak 82 responden $(87,2 \%)$ dengan prestasi belajar ASKEB Persalinan rendah diperoleh dari sikap belajar yang negatif. Dalam penelitian ini kelompok responden dengan sikap belajar yang negatif pada mata kuliah ASKEB Persalinan lebih besar dari pada responden dengan sikap belajar yang positif.

Berdasarkan uji statistic didapatkan $\mathrm{P}$ value $<\alpha(0,003<0,05)$ artinya ada hubungan yang signifikan antara sikap belajar dengan prestasi belajar mata kuliah ASKEB Persalinan. Dimana responden dengan sikap belajar negatif dapat memiliki peluang atau OR untuk mendapatkan nilai mata kuliah yang rendah sebesar 3,5 kali lebih tinggi dibandingkan responden dengan sikap belajar yang positif terhadap mata kuliah ASKEB Persalinan dengan rentang CI antara $(1,545-7,970)$.

Tabel 6

Hubungan Teman Sebaya dengan Prestasi Belajar Persalinan di Akademi Kebidana Prima Husada Bogor

\begin{tabular}{|c|c|c|c|c|c|c|c|c|}
\hline \multirow[t]{3}{*}{ Teman Sebaya } & \multicolumn{4}{|c|}{$\begin{array}{c}\text { prestasi belajar ASKEB } \\
\text { Persalinan }\end{array}$} & \multicolumn{2}{|c|}{ Jumlah } & \multirow[t]{3}{*}{$\begin{array}{c}\text { Nilai } \\
\mathbf{P}\end{array}$} & \multirow[t]{3}{*}{ OR } \\
\hline & \multicolumn{2}{|c|}{ Rendah } & \multicolumn{2}{|c|}{ Tinggi } & \multirow[b]{2}{*}{ n } & \multirow[b]{2}{*}{$\%$} & & \\
\hline & $\mathbf{n}$ & $\%$ & n & $\%$ & & & & \\
\hline Terpengaruh & & & & & & & 0.000 & $\begin{array}{r}7.286 \\
(3,040-\end{array}$ \\
\hline Tidak & 102 & 87,9 & 14 & 12,1 & 116 & 100.0 & & $17,461)$ \\
\hline Terpengaruh & 17 & 50,0 & 17 & 50,0 & 34 & 100.0 & & \\
\hline
\end{tabular}

Berdasarkan data tabel 6 di atas menunjukkan hubungan antara teman sebaya dengan prestasi belajar ASKEB Persalinan. Hasilnya adalah sebanyak 102 responden (87,9\%) dengan prestasi belajar ASKEB Persalinan rendah diperoleh dari karena terpengaruh teman sebaya. Dalam penelitian ini kelompok responden yang terpengaruh teman sebaya mendapat prestasi belajar rendah pada mata kuliah ASKEB Persalinan lebih besar dari pada responden yang tidak terpengaruh teman sebaya.

Berdasarkan uji statistic didapatkan $\mathrm{P}$ value $<\alpha(0,000<0,05)$ artinya ada hubungan yang signifikan antara teman sebaya dengan prestasi belajar mata kuliah ASKEB Persalinan. Dimana responden dengan terpengaruh teman sebaya dapat memiliki peluang atau OR untuk mendapatkan nilai mata kuliah yang rendah sebesar 7,3 kali lebih tinggi dibandingkan responden dengan tidak terpengaruh teman sebaya terhadap mata kuliah ASKEB Persalinan dengan rentang CI antara $(3,040-17,461)$. 


\section{Tabel 7 \\ Hubungan Motivasi Belajar dengan Prestasi Belajar di Akademi Kebidana Prima Husada Bogor}

\begin{tabular}{|c|c|c|c|c|c|c|c|c|}
\hline \multirow[t]{3}{*}{ Motivasi Belajar } & \multicolumn{4}{|c|}{$\begin{array}{c}\text { Prestasi Belajar ASKEB } \\
\text { Persalinan }\end{array}$} & \multicolumn{2}{|c|}{ Jumlah } & \multirow[t]{3}{*}{ Nilai P } & \multirow[t]{3}{*}{ OR } \\
\hline & \multicolumn{2}{|c|}{ Rendah } & \multicolumn{2}{|c|}{ Tinggi } & & & & \\
\hline & $\mathbf{n}$ & $\%$ & $\mathbf{n}$ & $\%$ & $\mathbf{N}$ & $\%$ & & \\
\hline $\begin{array}{ll}\text { - } & \text { Kurang Baik } \\
\text { - } & \text { Baik }\end{array}$ & $\begin{array}{l}70 \\
49\end{array}$ & $\begin{array}{l}88,6 \\
69,0\end{array}$ & $\begin{array}{c}9 \\
22\end{array}$ & $\begin{array}{l}11,4 \\
31,0\end{array}$ & $\begin{array}{l}79 \\
71\end{array}$ & $\begin{array}{l}100.0 \\
100.0\end{array}$ & 0.004 & $\begin{array}{c}3.492 \\
(1.482-8.229)\end{array}$ \\
\hline
\end{tabular}

Berdasarkan data tabel 7 di atas menunjukkan hubungan antara motivasi belajar dengan prestasi belajar ASKEB Persalinan. Hasilnya adalah sebanyak 70 responden $(88,6 \%)$ dengan prestasi belajar ASKEB Persalinan rendah diperoleh dari motivasi belajar yang kurang baik.Dalam penelitian ini kelompok responden dengan motivasi belajar yang kurang baik pada mata kuliah ASKEB Persalinan lebih besar dari pada responden dengan motivasi belajar yang baik.

Berdasarkan uji statistic didapatkan $\mathrm{P}$ value $<\alpha(0,004<0,05)$ artinya ada hubungan yang signifikan antara motivasi belajar dengan prestasi belajar mata kuliah ASKEB Persalinan. Dimana responden dengan motivasi belajar kurang baik dapat memiliki peluang atau OR untuk mendapatkan nilai mata kuliah yang rendah sebesar 3,5 kali lebih tinggi dibandingkan responden dengan motivasi belajar yang baik terhadap mata kuliah ASKEB Persalinan dengan rentang CI antara (1.482-8.229).

\section{PEMBAHASAN}

Prestasi belajar merupakan suatu masalah yang bersifat perenial dalam sejarah kehidupan manusia, karena sepanjang rentang kehidupannya manusia selalu mengejar prestasi menurut bidang dan kemampuan masing-masing. Prestasi belajar (achievement) semakin terasa penting untuk dibahas, karena mempunyai beberapa fungsi utama, antara lain sabagai: indikator kualitas dan kuantitas pengetahuan yang telah dikuasai peserta didik, lambang pemuasan hasrat ingin tahu, bahan informasi dalam inovasi pendidikan, indikator intern dan ekstern dari suatu institusi pendidikan dan indikator daya serap (kecerdasan peserta didik) (Arifin 2009).Berdasarkan hasil penelitian diketahui bahwa dari 150 mahasiswa terdapat 119 responden $(79,3 \%)$ mahasiswa yang mendapat prestasi belajar rendah dan 31 responden $(21,7 \%)$ mahasiswa mendapat prestasi belajar tinggi pada mata kuliah ASKEB Persalinan. Prestasi belajar ASKEB Persalinan rendah lebih banyak dari pada nilai ASKEB Persalinan yang tinggi.Sebelum melakukan penelitian terlebih dahulu telah dilakukan uji validitas dan reabilitas untuk menguji keseluruhan hasil pernyataan yang diberikan sehingga mendapat hasil tersebut.Hal ini di perkuat dengan penelitian yang dilakukan oleh Riska tahun 2011.Dengan kesimpulan hasil bahwa rendahnya prestasi belajar ASKEB Persalinan memang dapat di pengaruhi oleh faktor internal dan faktor eksternal.Berdasarkan data di atas dapat di simpulkan Mata kuliah ASKEB Persalinan merupakan salah satu mata kuliah yang harus dikuasai oleh mahasiswa pada tingkat II.Penguasaan mahasiswa terhadap mata kuliah ini dapat dilihat dari kemampuan dalam melakukan analisis terhadap kasus terkait dengan persalinan.Diharapkan mahasiswa mampu menguasai mata kuliah ini.Tetapi yang menjadi kendala adalah mata kuliah ASKEB Persalinan dianggap sulit oleh mahasiswa.

Kecerdasan emosional adalah kemampuan mengenali perasaan diri sendiri dan perasaan orang lain, memotivasi diri sendiri, serta mengelola emosi dengan baik pada diri sendiri dan dalam hubungan dengan orang lain. Berdasarkan hasil penelitian diketahui bahwa dari 150 mahasiswa terdapat 69 responden $(88,5 \%)$ mahasiswa memiliki kecerdasan emosional kurang baik, dan 50 responden $(69,4 \%)$ mahasiswa memiliki kecerdasan emosional baik. Nilai $\mathrm{P}$ value $=0,005$ dalam penelitian ini kecerdasan emosional mempunyai hubungan yang bermakna karena diketahui bahwa $<\alpha(0,005<0,05)$ berarti ada hubungan 
antara kecerdasan emosional dengan rendahnya prestasi belajar ASKEB persalinan.Adapun penelitian terdahulu mengenai hal terkait dengan kecerdasan emosional berdasarkan Penelitian oleh Umarianti (2011).Dengan hasil adanya hubungan yang positif dan signifikan antara harga diri dengan prestasi belajar dan dapat diarti-kan semakin baik harga diri maka prestasi belajar mahasiswa semakin baik juga. ada hubungan yang positif dan signifikan antara kecerdasan emosi dengan prestasi belajar dan dapat diartikan semakin baik kecerdasan emosi maka prestasi belajar mahasiswa semakin baik juga.Diperkuat juga oleh hasil penelitian oleh Purnaningtyas (2008).Dengan hasil bahwa terdapat hubungan yang positif dan signifikan antara kecerdasan emosi dengan prestasi belajar siswa.Dengan adanya hubungan antara kecerdasan emosi dan prestasi belajar mahasiswa pada mata kuliah ASKEB Persalinan, terdapat hubungan yang signifikan.hubungan yang signifikan tersebut dapat diartikan bahwa semakin tinggi kecerdasan emosi juga akan semakin tinggi prestasi belajarnya, sedangkan semakin rendah kecerdasan emosi maka prestasi belajar mahasiswa pada mata kuliah ASKEB Persalinan juga semakin rendah. Sehingga analisa menurut peneliti bahwa penelitian yang dilakukan di AKBID Prima Husada Bogor didapatkan banyaknya mahasiswa yang memiliki kecerdasan emosional kurang baik, hal tersebut dapat dikarenakan beberapa faktor yaitu lingkungan keluarga, non keluarga, stuktur otak, usia, dan jenis kelamin mereka dan juga karena mereka belum mampu menangani perasaan mereka sendiri dengan baik. Minat adalah suatu rasa lebih suka dan rasa ketertarikan pada suatu hal atau aktivitas, tanpa ada yang menyuruh. Berdasarkan hasil penelitian diketahui bahwa dari 150 mahasiswa terdapat 107 responden $(87,0 \%)$ mahasiswa memiliki minat belajar yang kurang baik dan 12 responden $(44,4 \%)$ mahasiswa memiliki minat belajar yang baik. Nilai $\mathrm{P}$ value $=0,000$ dalam penelitian ini minat belajar dengan prestasi belajar ASKEB persalian mempunyai hubungan yang bermakna karena diketahui $P$ value $0,000<0,05$ berarti ada hubungan antara minat belajar dengan prestasi belajar ASKEB persalinan.Adapun Penelitian terdahulu oleh Wijayanti (2011). Dengan hasil penelitian dinyatakan signifikan dan benar yang berarti ada hubungan minat dengan prestasi belajar pada mata kuliah Asuhan Kebidanan II. Dalam hal ini hasil berupa hubungan yang positif artinya minat yang tinggi akan diikuti dengan prestasi belajar yang memuaskan.Diperkuat juga oleh penelitian yang lakukan Nungroho (2012). Berdasarkan analisis data, maka terdapat hubungan yang signifikan antara minat belajar dan hasil belajar IPS termasuk dalam kategori sangat tinggi dan sumbangan atau pengaruh variabel $\mathrm{X}$ terhadap variabel $\mathrm{Y}$ mempunyai persentase sebesar 95\%. Sehingga analisa yang dilakukan peneliti, disimpulkan bahwa penelitian yang dilakukan di AKBID Prima Husada Bogor, cenderung lebih banyak mahasiswa yang memiliki minat belajar yang kurang baik, Dengan demikian dosen dalam belajar mengajar perlu berusaha menarik minat mahasiswa agar timbul perasaan senang terhadap mata kuliah ASKEB Persalinan karena mahasiswa belum mempunyai pengalaman langsung melakukan ASKEB Persalinan, sehingga masih belum tumbuh minat yang kuat menganai ASKEB Persalinan.

Sikap merupakan reaksi atau respon yang masih tertutup dari seseorang terhadap stimulus atau objek.Sikap itu tidak dapat langsung dilihat, tetapi hanya dapat ditafsirkan dahulu dari perilaku yang tertutup.Sikap secara nyata menunjukkan konotasi adanya kesesuaian reaksi terhadap stimulus tertentu. Berdasarkan penelitian yang dilakukan pada 150 mahasiswa terdapat Yang memiliki sikap belajar negatif 82 responden $(87,2 \%)$ mendapatkan prestasi belajar ASKEB persalinan rendah dan 37 responden $(66,1 \%)$ memiliki sikap belajar positif mendapat prestasi belajar ASKEB persalinan rendah. Selain itu dari uji statistik didapatkan $\mathrm{P}$ value $<\alpha(0,003<0,05)$ dalam penelitian ini ada hubungan yang signifikan antara sikap belajar dengan rendahnya prestasi belajar ASKEB persalinan. Hal ini sejalan dengan penelitian oleh Handayani (2008). Menyatakan hasil penelitinanya bahwa adanya hubungan positif yang signifikan antara pengetahuan, sikap, minat dan motivasi belajar dengan prestasi belajar, maka dapat dikatakan bahwa kondisi internal mahasiswa yang meliputi pengetahuan, sikap, minat dan motivasi belajar turut mendukungpencapaian prestasi belajar.Adapun penelitian yang dilakukan oleh Prihartini (2011).Dengan hasil penelitian yang dapat disimpulkan bahwa ada hubungan atau korelasi yang rendah antara sikap dengan prestasi belajar.Adapun analisa yang dilakukan peneliti mengenai penelitian yang dilakukan di AKBID Prima Husada Bogor mendapatkan hasil lebih banyak mahasiswa yang menerima mata kuliah ASKEB Persalinan dengan sikap yang negatif dibanding dengan sikap yang positif, Hal tersebut dapat disebabkan karena mahasiswa belum dapat menyikapi mata kuliah tersebut sebagai sumber untuk 
mendapatkan pengetahuan yang penting di lapangan, sehingga mahasiswa akan mempunyai kecenderungan menyikap negatif dalam mempelajari ASKEB Persalinan karena mereka akan menganggap mata kuliah tersebut belum sangat penting bagi mereka, yang akan menyebabkan menurunnya prestasi dalam belajar ASKEB Persalinan.

Kawan-kawan sebaya adalah anak-anak atau remaja yang memiliki usia atau tingkat kematangan yang kurang lebih sama, maka dapat disimpulkan bahwa teman sebaya adalah hubungan individu pada anakanak atau remaja dengan tingkat usia yang sama serta melibatkan keakraban yang relatif besar dalam kelompoknya. Berdasarkan penelitian yang dilakukan pada 150 mahasiawa yang terpengaruh teman sebaya mendapat prestasi belajar ASkEB persalinan rendah sebanyak 102 responden (87,9\%), dan 17 responden $(50,0 \%)$ tidak terpengaruh teman sebaya mendapat prestasi belajar ASKEB persalinan rendah. Nilai $\mathrm{P}$ value $=0,000$ dalam penelitian ini teman sebaya mempunyai hubungan yang bermakna karena diketahui bahwa $P$ value $(0,000>0,05)$ artinya ada hubungan yang signifikan antara teman sebaya dengan rendahnya prestasi belajar ASKEB persalinan.Hal ini sejalan dengan penelitian terdahulu oleh Huda (2013), yang menunjukan hasil penelitiannya bahwa, Peranan teman sebaya, berpengaruh signifikan terhadap hasil belajar (Sig=0,000).Diperkuat juga oleh penelitian yang dilakukan oleh Arjanggi (2010). Yang mempunyai hasil pembelajaran tutor teman sebaya mempunyai kontribusi sebesar 17,4 persen dalam meningkatkan hasil belajar berdasar regulasi-diri pada mahasiswa. Maka analisa yang dilakukan peneliti mengenai penelitian yang dilakukan di AKBID Prima Husada Bogor bahwa teman sebaya dapat mempengaruhi rendahnya prestasi belajar mereka, yang dikarenakan banyak faktor pemicunya yaitu interaksi sosial antara teman sebaya yang memicu terjadi saling mempengaruhi diantara individu satu dengan yang lainnya, sehingga dari anggapan yang diterima negatif akan menimbulkan mempengaruhi penerimaan dalam belajar menjadi menurun.

Motivasi adalah proses yang memberi semangat, arah, dan kegigihan perilaku. Berdasarkan hasil penelitian diketahui bahwa dari 150 mahasiswa yang kurang baik motivasi belajarnya sebanyak 70 orang $(88,6 \%)$ yang mendapatkan prestasi belajar ASKEB persalinan rendah, dan ada 49 orang $(69,0 \%)$ memiliki motivasi belajar yang baik mendapat prestasi belajar ASKEB persalinan rendah. Nilai $\mathrm{P}$ value $=$ 0,004 dalam penelitian ini motivasi belajar mempunyai hubungan yang bermakna karena diketahui bahwa $\mathrm{P}$ value $(0,004<0,05)$ artinya ada hubungan yang signifikan antara motivasi belajar dengan rendahnya prestasi belajar ASKEB persalinan.Hal ini sesuai dengan penelitian yang dilakukan oleh Hajar (2010).Dengan hasil penelitiannya bahwa Motivasi belajar mempunyai korelasi positif dan meyakinkan terhadap prestasi belajar sebesar 0,570 pada tingkat korelasi sedang. Motivasi belajar mempunyai sumbangan efektif sebesar 32,49\% terhadap prestasi belajar.Didukung juga oleh penelitian yang dilakukan oleh Rohmah (2010). Yang memiliki hasil analisis dari data uji statistik adalah $\mathrm{r}=+0,570$ dengan signifikansi 0,000 ( $\mathrm{P}<0,005)$ sehingga hipotesis diterima. Artinya terdapat hubungan positif dan signifikan antara motivasi belajar dengan prestasi belajar pada tingkat korelasi sedang. Sehingga analisa yang dilakukan oleh peneliti, dapat disimpulkan bahwa agar mahasiswa dapat mencapai hasil belajar ASKEB Persalinan yang tinggi dan maksimal harus diperkuat dengan adanya motivasi terhadap mata kuliah ASKEB Persalinan, oleh karena itu bagi mahasiswa yang prestasi belajar rendah perlu dibangkitkan motivasi yang tinggi dalam dirinya untuk mempelajari mata kuliah ASKEB Persalinan, dapat dengan memberi dorongan dengan suatu perbuatan yaitu dorongan belajar untuk mencapai hasil belajar yang optimal.

\section{KESIMPULAN DAN SARAN}

Penelitian ini dilakukan untuk mengetahui faktor-faktor yang berhubungan denganPrestasi Belajar Mata Kuliah Asuhan KebidananPersalinan Pada Mahasiswa Di Akademi Kebidanan Prima Husada Bogor Tahun 2015. Adapun faktor-faktor terkait yaitu kecerdasan emosional, minat, sikap, teman sebaya dan motivasi. Setelah dilakukan analisis dan uji statistik diperoleh kesimpulan sebagai berikut:

1. Frekuensi responden yang mendapatkan prestasi belajar ASKEB Persalinan rendah lebih banyak dari pada responden yang mendapatkan prestasi belajar ASKEB Persalian tinggi.

2. Ada hubungan antara kecerdasan emosional dengan Prestasi Belajar ASKEB Persalinan pada mahasiswa DIII kebidanan di Akademi Kebidanan Prima Husada Bogor Ada hubungan antara minat 
belajar dengan Prestasi Belajar ASKEB Persalinan pada mahasiswa DIII kebidanan di Akademi Kebidanan Prima Husada Bogor

3. Ada hubungan antara sikap belajar dengan Prestasi Belajar ASKEB Persalinan pada mahasiswa DIII kebidanan di Akademi Kebidanan Prima Husada Bogor Ada hubungan antara teman sebaya dengan Prestasi Belajar ASKEB Persalinan pada mahasiswa DIII kebidanan di Akademi Kebidanan Prima Husada Bogor

4. Ada hubungan antara motivasi belajar dengan Prestasi Belajar ASKEB Persalinan pada mahasiswa DIII kebidanan di Akademi Kebidanan Prima Husada Bogor.

\section{DAFTAR PUSTAKA}

A Choiriah, 2013, Pengaruh Kecerdasan Emosional, KecerdasanIntelektual, Kecerdasan Spiritual Dan Etika Profesi Terhadap Kinerja Auditor Dalam Kantor Akuntan Publik. Skripsi Jurusan Akuntansi Fakultas Ekonomi. Universitas Negeri Padang. Sumatra Barat

A Ifham, A. 2002 .Hubungan Kecerdasan Emosi Dengan Kewirausahaan Pada Mahasiswa. Skripsi Fakultas Psikologi. Universitas Gajah Mada. Yogjakarta

Aripin.Z. (2011). Evaluasi Pembelajaran. Bandung : PT. Remaja Rosdakarya.

Arikunto, S. (2013).Prosedur Penelitian Suatu Pendekatan Praktik. Jakarta: PT Rineka Cipta.

Arjanggi, (2010).Metode Pembelajaran Tutor Teman Sebaya Meningkatkan Hasil Belajar Berdasar Regulasi-Diri. Fakultas Psikologi, UniversitasIslam Sultan Agung (Unissula) Semarang. Indonesia

Azwar, Saipudin. (2010). Sikap Manusia.Yogyakarta : Liberty

Dalyono. (2005). Psikologi Pendidikan.Jakarta : Rineka Cipta

Goleman, D. (2009). Emotional Intelligence, Mengapa EI lebih penting daripada IQ (Terjemahan : T. Hermaya . Jakarta: PT. Gramedia Pustaka Utama.

Gottman, J dan De Claire, J. (2005).Kiat-kiat Membesarkan Anak Yang MemilikiKecerdasan Emocional. Jakarta : PT. Gramedia Pustaka Utama.

Hamalik, Oemar .(2007). Proses Belajar Mengajar. Jakarta: Bumi Aksara

Hidayat, A. (2007). Metode Penelitian Kebidanan \& Teknik Analisis Data Jakarta : Salemba Medika

Notoatmojdjo, S. (2012).Metodologi Penelitian Kesehatan. Jakarta : Rineka Cipta.

Prihartini, (2011).Hubungan Sikap dan Motivasi dengan Prestasi Belajar Mata Kuliah Keterampilan Dasar Praktik Klinik Program Studi Diploma III Kebidanan Fakultas Ilmu Kesehatan Universitas Pesantren Tinggi Darul Ulum Jombang

Purnaningtyas, ( 2008).Pengaruh Kecerdasan Emosi Terhadap Prestasi Belajar Siswa Mata Pelajaran Seni Budaya SMP

Purwanto, Ngalim. (2004). Psikologi Pendidikan.Bandung : PT. Remaja Rosda Karya

Riduwan, (2013).Metode dan Teknik Menyusun Tesis. Bandung: ALFABETA

Rohmah, (2010). Hubungan Antara Motivasi Belajar dengan Prestasi Belajar Mata Kuliah Askeb 3 Mahasiswa Prodi DIV Kebidanan FK UNS Tahun Ajaran 2009/2010.Semarang

Safari.2005.Penulisan Butir Soal Berdasarkan Penilaian Berbasis Kompetensi.Jakarta:APSI Pusat Santrock. (2009). Psikologi Pendidikan / Educational Psychology, Jakarta : Salemba Humanika.

Sardiman.(2011).Interaksi dan Motivasi Belajar Mengajar.Jakarta : Rajawali Pers

Shapiro. (2003). Kecerdasan Emosional pada Anak. Jakarta : Gramedia

Slameto.(2013). Belajar dan Faktor - Faktor yang Mempengaruhinya. Jakarta: Rineka Cipta.

Sudjana, N. (2009). Penelitian Hasil Proses Belajar Mengajar. Bandung: PT RemajaRosdayakarya.

Sugiyono. (2011). Metode Penalitian Kuantitatip, kualitatip dan $R \& D$. Bandung:ALFABETA

Suharno. (2009). Langkah Jitu Memulai Bisnis dari Nol. Jakarta : Penebar 
Swadaya.

Syah, Muhibbin.(2009).Psikologi Belajar. Jakarta:Rajawali Pers

Tu'u, T. 2004.Peran Disiplin Pada Perilaku dan Prestasi Siswa.Jakarta: PT.Grasindo.

Tresia.(2011). hubungan harga diri dan kecerdasan emosi dengan prestasi belajar pada mata kuliah asuhan kebidanan IV Patologi mahasiswa semester VII di prodi DIV. Skripsi Jurusan Kebidanan. Universitas SebelasMaret. Surakarta

TIM .(2007).Kamus Besar Bahasa Indonesia.Jakarta : Balai Pustaka

Wijayanti.(2011). Hubungan Antara Minat Baca dengan Prestasi Belajar pada Mata Kuliah Asuhan Kebidanan II pada Mahasiswa Semester III Akbid Mitra Husada Karanganyar. Karanganyar.Banten 